\title{
International experience of territorial-spatial organization of university campuses in urban structure
}

\author{
Monica-Nataliia Wagner $^{*}$ and Umeda Ovezova ${ }^{1}$ \\ ${ }^{1}$ Peoples' Friendship University of Russia (RUDN University), Moscow, Russia
}

\begin{abstract}
Universities are important structural and functional elements of megalopolises, they carry out professional training of specialists for various spheres of society; in addition, they are scientific and cultural centers. Nowadays the issues of education improvement, in particular, its spatial organization, are especially important. In this regard, this work analyzes international experience of spatial organization of university campuses in urban structure, including determination of major forms of territorial-spatial organization of university campuses and approaches to territorial-spatial development of campuses both in urban structure and in the campus territory.

Keywords: university, territorial-spatial organization, territorial-spatial development, campus.
\end{abstract}

\section{Introduction}

Activity of universities stipulates varies areas of life: educational, scientific, cultural, recreational, sporting and casual, which are usually implemented by organization of certain areas in urban structure. Dynamism of current life, socio-cultural trends affect, as never before, the need for the organization of new forms of living, learning and research activity, recreation and sports activity of students. Modern Russian educational system has been seriously transformed: priorities in demands of society regarding higher education, its structure and content have been changed, new standards have been introduced. Wider organization independence granted to universities exerts influence on formation of training and material base and encourages respective modification of their structural and functional organization. The strategy of sustainable urban development requires for a new glimpse on reasonable application of university campuses in their structure.

These processes stipulate occurrence of complicated problems for further development of universities in country and require for their solution. The existing predictable forms of development of university campuses in urban structure require for scientific substantiation.

* Corresponding author: umeda 77@mail.ru 


\section{Methods}

The conceptual base of the research was comprised of the works devoted to the issue of organization of university environment in megalopolis structure; principles of territorialspatial organization of university structure; strategic development of universities in modern sphere of economic theory, management and marketing.

The research objective was to analyze international experience of territorial-spatial organization of university campus in urban structure on the basis of available publications.

The formulated objective was achieved by general scientific analysis of scientific publications devoted to the research problem.

\section{Results}

\subsection{Main forms of territorial-spatial organization of university campuses}

Analysis of foreign experience of territorial-spatial organization of university campuses has allowed to detect their two main types (two main forms of their territorial-spatial organization) (Table 1).

Table 1. Main forms of territorial-spatial organization of university campuses.

\begin{tabular}{|c|c|l|}
\hline No. & Form & \multicolumn{1}{c|}{ Properties } \\
\hline 1 & campus & $\begin{array}{l}\text { spatial integrity and relative independence in urban structure } \\
{[1,2]}\end{array}$ \\
\hline 2 & $\begin{array}{c}\text { modern organization of } \\
\text { university }\end{array}$ & $\begin{array}{l}\text { spatial separation and increased integrity of functional } \\
\text { blocks into urban structure [3, 4] }\end{array}$ \\
\hline
\end{tabular}

According to the experts' opinion, the first type, historical form of campus, is the most successful model of territorial-spatial formation of university. The modern campus layouts of Europe and the United States originate from the traditional form of monasteries and their spatial planning principles. This is attributed to the fact that campuses were surrounded by communities, which embedded this territorial-spatial form [5].

The territory of classic campus is generally comprised of teaching block, researching laboratories, student residences (dormitories), libraries, sports grounds and halls, recreational areas, various places of public catering and trade, etc., which allows to provide higher independence of this territory on urban structures [6].

Thus, Yale University is located in central districts of the oldest city of New England: New Haven, Connecticut (USA). Yale University is comprised of territorially autonomous and closed campuses, some of which are located in central districts, some - in peripheral districts. In general, the university composition is characterized by elongated form, comfort pedestrian links inside the campuses but inconvenient pedestrian communications between the university campuses [7].

Another example is Middle East Technical University in Ankara, Turkey. Its territory occupies 4,500 ha, including 3,043 ha of recreational areas. There are also teaching blocks, residential buildings, libraries and researching laboratories, sports grounds, public service buildings (banks. shops, coffee rooms, etc.). Its structure is characterized by distinct links between the areas and their reasonable location with regard to each other [8].

Therefore, it is possible to highlight the following main properties of territorial-spatial organization of classic campuses:

- localization of object in urban territory or its periphery,

- subdivision of object territory into recreational area, learning and administrative area, residential area, service and sports area, 
- protection of campus territory, distinct boundaries,

- independence on urban structures,

- existence of infrastructure in the campus territory (pedestrian, transport links).

The second type is comprised of integrated universities, which are characteristic for European countries. Universities of this type were formed in 18-19 centuries in central urban districts, their development was characterized by territorial-spatial segmentation $[9,10]$.

This type of universities can be exemplified by Columbia University in the City of New York (USA). The main building is located on $116^{\text {th }}$ Street and Broadway, Manhattan. The campus is located in the center of New York and partially integrated into the city. Some buildings of the university are located in adjacent office and residential districts. The campus structure is comprised of administrative area, training area, sports area, cultural and entertainment area, residential and recreational area [11].

Institute of Psychiatry is located to the west of center, and the Biometric Research and Engineering Park is located to the east from Broadway. In addition, the University has two facilities beyond the Manhattan [12].

Therefore, the university structure is comprised of several independent campuses, which are located in the central districts of New York.

\subsection{Territorial-spatial development of university campuses}

Territorial-spatial development of campuses and university towns of European countries and USA mainly takes place in the boundaries of campuses, or new university towns are erected according to the campus model in an undeveloped area, mainly in urban periphery.

The analysis of international experience has revealed several methods of territorial-spatial development of university campuses both in urban structure and in the campus territory (Table 2).

Table 2. Methods of territorial-spatial development of university campuses.

\begin{tabular}{|c|l|}
\hline No. & \multicolumn{1}{c|}{ Method of territorial-spatial development } \\
\hline 1 & reconstruction and renovation of territories adjacent to university campus \\
\hline 2 & $\begin{array}{l}\text { co-operating of several universities and research centers in independent educational } \\
\text { research center aiming at detachment of teaching area of university }\end{array}$ \\
\hline 3 & $\begin{array}{l}\text { rational utilization of campus territory: } \\
\text { - maintenance of roof and terrace, } \\
\text { - organization of pathways between buildings, which will act both as connecting } \\
\text { pedestrian elements and as additional space for cultural, entertainment, and } \\
\text { information and communication functions of university }\end{array}$ \\
\hline
\end{tabular}

Method 1 is widely used due to reconstruction and renovation of deteriorated and unsuitable for living districts. Thus, the Manhattanville campus project has been developed stipulating for spatial development of Columbia University in the City of New York using separate area close to the main building. Therefore, the concept of spatial growth of the University due to reconstruction of adjacent poor districts solves architectural and urban planning, social, cultural and economic problems not only of the University but also of the city [13].

Method 2 of co-operating of several universities, research and educational recreational centers is widely used in various countries of the world. For instance, Espace Bienvenue research and development center in Marne-la-Vallée (France) stipulates for co-operating of several universities and research centers. Total area of the complex is 3.5 ha. In addition, rational use of eco-resources is stipulated [14]. 
The use of Method 3 is also observed in the project of research and development complex: rational application of land resources due to densification of functions. The project stipulates for maintenance of roof as a public place for recreation and communication (Botanical Research Institute of Texas, University of Massachusetts Amherst, California Academy of Sciences, South China University of Technology, etc.) [14].

Such rational use of land resources allows to reduce the surface area of university campus in densely populated areas of urban central districts. At the same time, modifications of campuses into multifunctional vertical complexes aiming at decrease in occupied areas seem to be sufficiently relevant [15] (eco-campus of Asia Pacific University of Technology and Innovation in Malaysia, energy-saving student town in Miami, project of new campus of Singapore University of Technology and Design, etc.)

\section{Conclusion}

Analysis of international experience has allowed to determine two main types of universities in terms of their territorial-spatial organization: compact (campus, steady historical form) and segmented form of organization.

Territorial-spatial development of campuses of foreign countries takes place by internal reconstruction of campus territories, construction of new university towns on the basis of campus model in an undeveloped area, mainly in urban periphery.

The second type of territorial-spatial organization of universities is characterized by territorial segmentation. Thus, their development is based on certain spatial methods: reconstruction of territories adjacent to university campus; co-operating several universities and research centers in independent educational research center aiming at development of teaching area of university; intensive use of campus territories.

\section{References}

1. A. Jovanovic, E.M. Kandjani, M. Dacic, Connection of Spaces in Campus Planning and Design, in Proceedings of the IVth International Symposium for Students of Doctoral Studies in the Fields of Civil Engineering, Architecture and Environmental Protection, University of Nis Faculty of Civil Engineering and Architecture, 27-28 September 2012, Nis, Serbia, 93-98 (2012)

2. K.S. Huang, The Journal of Architecture, 59, 189-202 (2007)

3. S. Diner, Metropolitan Universities Journal, 23(3), 61-77 (2012)

4. K. Hoeger, Campus and the city. A joint venture? in Campus and the city. Urban design for the knowledge society, 13-22 (Verlag, Zurich, 2007)

5. Z. Chen, J. Guo, Historical Sources of University Campus Form and its Relationship with Urban Space, in Proceedings of the 3rd International Conference on Smart City and Systems Engineering (ICSCSE), 29-30 December 2018, Xiamen, China, vol. 1, 746-749 (2018). https://doi.org/10.1109/ICSCSE.2018.00160

6. A.C. Den Heijer, F.T.J. Curvelo Magdaniel, International Journal of Knowledge-Based Development, 3(3), 283-304 (2012). https://doi.org/10.1504/ijkbd.2012.048392

7. Yale University. A Framework for Campus Planning. (Cooper, Robertson \& Partners Architecture, Urban Design, 2000)

8. O. Altintasi, H. Tuydes-Yaman, Assessing Sustainable Campus Transportation Policies for METU: Policies for In-Campus Mobility, in Proceedings of the 10th International Congress on Advances in Civil Engineering, Middle East Technical University, 17-19 October 2012, Ankara, Turkey, 1-12 (2012). 
9. G. Schmitt, Three conditions for successful campus planning, in Campus and the city. Urban design for the knowledge society, 25-33 (Verlag, Zurich, 2007)

10. S.R. Hill, National Forum: Phi Kappa Phi Journal, 61(3), 38-39 (1981)

11. Columbia University in the city of New York, Morningside Heights Self-Guided Walking Tour (n.d.). Accessed on: December 20, 2020. [Online]. Available: http://www.columbia.edu/files/columbia/content/walking-tour-and-map-3.pdf

12. Columbia University in the city of New York. Self-Guided Walking Tour (n.d.). Accessed on: December 20, 2020. [Online]. Available:

https://visit.columbia.edu/sites/default/files/content/Final\%20VC\%20updated\%20walk ing-tour-and-map.pdf

13. M. Taylor, Places, 17(1), 50-53 (2005).

14. A. Gunn, The European Universities Initiative: A Study of Alliance Formation in Higher Education, in European Higher Education Area: Challenges for a New Decade, 13-30 (Springer, Cham, 2020)

15. H. Tan, S. Chen, Q. Shi, L. Wang, The Journal of Cleaner Production, 64, 646-653 (2014). https://doi.org/10.1016/j.jclepro.2013.10.019 